\title{
Is Health Management of the COVID-19 Pandemic a Cause of Agricultural Commodity Prices? New Evidences From Bootstrap Fourier Causality Test
}

\author{
COVID-19 Pandemisinin Sağlık Yönetimi Tarımsal Emtia Fiyatlarının bir Nedeni midir? Bootstrap \\ Fourier Nedensellik Testinden Yeni Kanitlar
}

\author{
Erdal Tanas KARAGÖL ${ }^{1}$ \\ (D) 0000-0003-0803-4064 \\ Mert AKYÜZ ${ }^{1}$ \\ (D) 0000-0002-2322-3384 \\ Çağın KARUL ${ }^{2}$ \\ (i) 0000-0002-5856-930X
}

\begin{abstract}
${ }^{1}$ Ankara Yıldırım Beyazıt University Faculty of Political Sciences Department of Economics, Ankara, Turkey

${ }^{2}$ Pamukkale University Faculty of
\end{abstract} Economics and Administrative Sciences Department of Econometrics, Denizli, Turkey
}

\section{Corresponding Author Sorumlu Yazar Mert AKYÜZ makyuz@ybu.edu.tr}

Received / Geliş Tarihi : 15.01.2021 Accepted / Kabul Tarihi : 12.03.2021 Available Online /

Çevrimiçi Yayın Tarihi : 23.03.2021

\begin{abstract}
Aim: Coronavirus disease 2019 (COVID-19) pandemic have included negative consequences both in health management and economic life at national and international level. The aim of this research is to examine the causal relationship between COVID-19 pandemic and agricultural commodity prices for the world.

Material and Methods: To this end, we employ Toda-Yamamoto and Fourier Toda-Yamamoto causality tests for the period of January 24, 2020 to January 22, 2021. Before testing the causal relationship between variables, we apply augmented Dickey Fuller (ADF) and Fourier ADF unit root tests to each series to determine maximum order of integration.

Results: The findings show that all variables are stationary in their first difference and the maximum order of integration is determined as 1 . The results obtained from causality tests show that COVID-19 new cases Granger cause to coffee, sugar, cotton, corn, and soybean prices while COVID-19 new cases do not cause wheat and oats prices. It was also concluded that new deaths based on COVID-19 Granger cause to coffee, sugar, and cotton whereas COVID-19 new deaths do not cause to corn, soybean, wheat and oat prices.

Conclusion: In this study, time series analysis based on Toda-Yamamoto and Fourier TodaYamamoto causality tests highlight that the COVID-19 total new cases and total new deaths in the world has predictive power to predict further prices of agricultural commodities. Therefore, in terms of health management, policy makers should give substantial significance to the implementation of COVID-19 related health policies and agricultural policies together during the COVID-19 pandemic period.

Keywords: Coronavirus; public health; commodity markets; Granger causality.
\end{abstract}

\section{ÖZ}

Amaç: Koronavirüs hastalığı 2019 (coronavirus disease 2019, COVID-19) pandemisi ulusal ve uluslararası düzeyde hem sağlık yönetiminde hem de ekonomik hayatta olumsuz sonuçlar doğurmuştur. Bu araştırmanın amacı, COVID-19 salgını ile dünya için tarımsal emtia fiyatları arasındaki nedensellik ilişkisini incelemektir.

Gereç ve Yöntemler: Bu amaçla, 24 Ocak 2020 - 22 Ocak 2021 dönemi için Toda-Yamamoto ve Fourier Toda-Yamamoto nedensellik testleri kullanılmıştır. Değişkenler arasındaki nedensellik ilişkisini test etmeden önce, maksimum entegrasyon derecesini belirlemek için her bir seriye augmented Dickey Fuller (ADF) ve Fourier ADF birim kök testleri uygulanmıştır. Bulgular: Bulgular, tüm değişkenlerin ilk farklarında durağan olduğunu ve maksimum entegrasyon derecesinin 1 olarak belirlendiğini göstermiştir. Nedensellik testlerinden elde edilen sonuçlar, COVID-19 yeni vakalarının kahve, şeker, pamuk, mısır ve soya fiyatlarının Granger nedeni olduğunu gösterirken COVID-19'a bağl1 yeni vakaların buğday ve yulaf fiyatlarının Granger nedeni olmadığını göstermiştir. Ayrıca COVID-19'a bağlı yeni ölümler kahve, şeker ve pamuk fiyatlarının Granger nedeni olurken COVID-19 ölümlerinin ise mısır, soya fasulyesi, buğday ve yulaf fiyatlarının Granger nedeni olmadığı sonucuna varılmıştır.

Sonuç: Bu çalışmada, Toda-Yamamoto ve Fourier Toda Yamamoto nedensellik testlerine dayalı zaman serisi analizi dünyadaki COVID-19 toplam yeni vakalarının ve toplam yeni ölümlerin tarımsal emtia fiyatlarını tahmin etme gücüne sahip olduğunu vurgulamaktadır. $\mathrm{Bu}$ nedenle sağlı yönetimi açısından politika yapıcılar, COVID-19 pandemisi döneminde COVID-19 ile ilgili sağlı politikaları ve tarım politikalarının birlikte uygulanmasına büyük önem vermelidir.

Anahtar kelimeler: Koronavirüs; halk sağlığı; emtia piyasaları; Granger nedensellik. 


\section{INTRODUCTION}

The world has faced an unprecedented pandemic crisis to date. Coronavirus disease 2019 (COVID-19) emerged in China, spread all over the world quickly, and caused great damage to the economies in a very short time. After China informed the World Health Organization (WHO) on December 31, 2019, the disease spread rapidly to Europe, Asia, and America. The first cases were seen in the US and France on January, 21 and January, 24 in 2020, respectively. WHO announced that it described the coronavirus disease as a pandemic on March 11, 2020 (1), and after this date, social and economic lives in countries began to slow down. The disease was transmitted very quickly, the deaths it caused increased day by day. At the beginning of the pandemic, there was no vaccine or drug developed to control it. Therefore, the most effective method of dealing with the virus was to reduce social mobility. Since the circulation of people, capitals, goods and services together with the developments in communication and transportation technologies in recent years has led to the rapid spread of the pandemic, maintaining social distance was the most effective method to reduce the transmission rate of the disease (2-4).

Countries without rich natural resources (oil, natural gas, precious metals, etc.), a reserve currency, and high government debts have been severely affected by COVID-19 pandemic. Measures taken to maintain social distance after the outbreak started deeply affected these countries. Working from home, not traveling very often, closing schools, shutting down the borders led to a decrease in consumption and production of goods and services in some sectors. This process caused economies to come to a standstill. Households working from home and not going out caused demand to slow down, and thus contractionary demand and curfews led to the firms to decrease supply. Therefore, the COVID-19 pandemic emerged as an external shock not caused by the dynamics of the economy itself and the measures taken against the pandemic caused a decrease in both consumption and production. As a result of the slowdown in supply and demand, the households' income and firms' profit decreased. The deterioration of cash flows of individuals and companies started to affect financial markets gradually. Increasing volatility in financial markets raised the fragility of economies in the next period and increased the risk of entering into recession. Economic policies such as tax cuts and credit expansions were implemented to increase the demand and supply against the external health shock and aimed at reducing costs of pandemic. However, decline in both supply and demand due to the COVID-19 outbreak revealed that traditional economic policies to stimulate supply and demand were insufficient. The rapid spread of the disease in countries substantially forced economy administrations to take extraordinary measures. Developed and developing countries started to carry out unconventional monetary and fiscal policies in order to both prevent decrease in supply and provide stimulation in demand. Direct cash supports were provided to lowincome households, corporate and social security taxes were postponed, unemployment insurance and paid leave to families with children were continually given (5-7).

COVID-19 has put an extreme burden on the health systems of countries and these burdens have negatively affected health management. Lack of good governance, inadequacy in finance, reduction in service delivery, insufficiency in equipment and workers have been the most adversely influenced components of health managements (8-10). Furthermore, information has special place in health management (11). With regard to coronavirus pandemic, a lack of information about COVID-19 cases and deaths leads to inefficient decision-making process in economic and social policies (12). The deterioration in health management systems due to the COVID-19 pandemic has also affected the agricultural products market through complex structure of the world economy $(13,14)$. Hence, the question of whether COVID-19 cases and deaths in the world provide considerable information about agricultural commodities needs to be answered.

It is argued that coronavirus has had an impact on commodity markets and has been one of the hot debated topics among policy makers (15). From economics perspective, aggregate supply and demand shocks affect commodity prices severely and cause to disruption in quantity supplied and demanded. Commodity prices fluctuate and deviate from equilibrium prices when external shock hit to the open economies. Accordingly, the price adjustment mechanism operates instantaneously in commodity markets and commodity prices are adjusted until which quantity supplied is equal to quantity demanded $(16,17)$. One of the main concerns for policymakers from the beginning of COVID-19 has been to provide food supply security and price stability (18-20). In terms of supplying food, the COVID-19 disease has created difficulty in agribusiness industry, in particular supply channels for agricultural products have been interrupted due to the closed borders between countries and lockdowns in cities (20,21). In light of these developments for agricultural commodities and COVID-19 pandemic, it is very essential to quantify how COVID-19 pandemic has an influence on agricultural commodities. We therefore investigate the impact of new cases and deaths caused by COVID-19 in the world on agricultural commodity prices.

There is large body of literature examining the relationship between COVID-19 and economic-financial variables. The discussion about the effect of COVID-19 pandemic has centered on stock markets (22-31), gold and oil prices (32-36), and volatility (37-41). Considering the impact of COVID-19 spread on the economic-financial variables, the empirical results of these studies mostly vary across countries, methods, and periods. The recent study (42) probes the determinants of inflation for European Union member states in the COVID-19 pandemic period. Using spatial panel data analysis, this study concludes that inflation in European Union countries has been affected by member states and internal market and thus cooperation and coordination in macroeconomics in European Union are crucial to mitigate the adverse effects of COVID-19 pandemic. Contrary to the immense analysis of the COVID-19 effect on macroeconomic and financial indicators, the impact of COVID-19 pandemic on agricultural commodity markets has received little empirical attention. One of these studies (43) examined the causal relationship between COVID-19 total deaths and agricultural commodity prices. 
This research includes corn, oats, rapeseed, soybeans, wheat prices and employs vector error correction model (VECM) and Granger causality test based on continuous wavelet transform. According to the results of VECM based Granger causality test, COVID-19 deaths granger causes to corn, oats, and rapeseed spot prices, which direction is running from deaths to spot prices. However, it was found that there is no causality from COVID-19 deaths to soybean prices. Another research (16) examined the effect of COVID-19 induced economic uncertainty on the volatility of S\&P GSCI commodity index, crude oil, and gold prices by using vector autoregressive (VAR) model. The results of this study show that one standard deviation increase in world pandemic uncertainty leads to about $1.9 \%$ decrease in commodity volatility. Positive COVID-19 uncertainty shock causes to 270 basis points reduction in oil price volatility. On the other hand, one standard deviation shock in world pandemic uncertainty leads to approximately 30 basis point decrease in gold price volatility. One study (44) analyzed the potential impact of COVID-19 on the prospects of agricultural markets by utilizing on IMF economic growth forecasts with global-multi-commodity agricultural market model. The findings of this study indicate that decrease in the economic growth is expected to a $7-18 \%$ decrease in meat prices, $4-7 \%$ reduction in dairy products, $3.5-7 \%$ decline in grains, and $5-9 \%$ fall in oilseeds, respectively. On the other hand, COVID-19 pandemic is expected to a $1 \%$ or 50 million tones decrease in greenhouse gases based on agricultural production. One of the recent studies (45) inspected the impact of oil and global demand on volatility of commodity prices during the COVID-19 pandemic. The empirical results of this study suggest that positive shock in oil prices lead to positive response of wheat and corn prices while response of soybeans and rice price are negative. Positive shock in oil price volatility causes to negative agricultural price returns. Gold and silver give negative response to oil shock whereas copper prices respond positively to oil shock. Furthermore, aluminum price responds positively to oil price shock. Other research (46) examined the relationship between sugar price and financial uncertainty in times of COVID-19 pandemic. According to the results of this study, since 2008 global economic crisis, there is a significant and negative relationship between sugar price and financial uncertainty. However, the results obtained from regression analysis present that during the COVID-19 term, there is no structural change between sugar price and financial uncertainty.

By reviewing literature, it is obvious that there is lack of empirical studies concerning the relationship between COVID-19 pandemic and agricultural commodity prices. Hence this research is reasonable initiative to fill this gap by examining the impact of COVID-19 new cases and new deaths on coffee, sugar, cotton, corn, soybean, wheat, oats prices. There are also two other contributions of this research: first, the period is extended and covering from 24 January 2020 to 22 January 2021; second, we utilized the Fourier based causality test (hereafter Fourier TodaYamamoto) newly introduced by Nazlioglu et al. (47). The advantage of using Fourier Toda-Yamamoto causality test is to consider the structural changes in data since conventional causality tests in time series analysis assume no sharp and smooth changes. In addition, studies investigating the association between COVID-19 cases or deaths and agricultural commodity prices $(43,44)$ do not consider the smooth structural changes. Thus, one of the important contributions of this study in the COVID-19 literature is to employ Fourier Toda-Yamamoto causality test in examining the link between COVID-19 deaths and cases and agricultural commodity prices. The expected new insight gained by applying the Fourier Toda-Yamamoto causality test is to find a causal link running from COVID-19 cases and deaths to agricultural commodity prices.

\section{MATERIAL AND METHODS}

\section{Causality Tests}

Since Wald statistic does not follow a chi-square distribution if the series are integrated, we utilize Toda and Yamamoto (TY) test (48) instead of Granger (49) causality test. Because this approach overcomes the problem by using level data and estimating $\operatorname{VAR}(p+d)$ model where $d$ represents the maximum integration order of variables. They define $V A R(p+d)$ model as

$y_{t}=Z_{t}+J_{1} y_{t-1}+\cdots+J_{p+d} y_{t-(p+d)}+\varepsilon_{t}$

where $Z_{t}$ represents the deterministic terms, $y_{t}$ consists of endogenous variables, $J$ shows the coefficient matrices and $\varepsilon_{t}$ are independent and identically distributed errors. TY approach does not consider any structural changes in data. Enders and Jones (50) show that the Granger causality analysis may provide misleading inferences if structural changes in data are improperly modelled or ignored. Nazlioglu et al. (47) extends the TY approach by considering smooth structural breaks using Fourier approximation. They define the deterministic terms with single frequency as follows:

$Z_{t} \cong \alpha_{0}+\alpha_{1} t+\alpha_{2} \sin \left(\frac{2 \pi k t}{T}\right)+\alpha_{3} \cos \left(\frac{2 \pi k t}{T}\right)$

where $\alpha_{2}$ and $\alpha_{3}$ measures the amplitude and displacement of the frequency, respectively and $k$ represents the Fourier frequency. Then, we can write the $\operatorname{VAR}(p+d)$ model as

$$
\begin{aligned}
y_{t}=\alpha_{0}+\alpha_{1} t+ & \alpha_{2} \sin \left(\frac{2 \pi k t}{T}\right)+\alpha_{3} \cos \left(\frac{2 \pi k t}{T}\right) \\
& +J_{1} y_{t-1}+\cdots+J_{p+d} y_{t-(p+d)}+\varepsilon_{t}
\end{aligned}
$$

Nazlioglu et al. (47) utilizes Wald statistic to test the null hypothesis of Granger non-causality based on zero restrictions on the first $p$ parameters. Since Wald test depends on the Fourier frequency, $k$, it may not have a chi-square distribution. To overcome this problem, they obtain bootstrap distribution of Wald statistic.

The standard Toda-Yamamoto and Fourier TodaYamamoto causality tests require determining the lag lengths $(p)$ and the number of Fourier frequency $(k)$. Following Nazlioglu et al. (47), we benefit from Schwarz information criterion to determine the optimal number of lags and the number of Fourier frequency. Specifically, we set the number of lags to $p^{\max }$ and the number of Fourier frequency to $k^{\max }$ and select the optimal number of $p$ and $k$ that yields the smallest information criterion value. 


\section{Data}

To investigate the relationship between COVID-19 pandemic and agricultural commodity prices in the world, this research employed a dataset involved of 252 daily observations for prices of coffee, sugar, cotton, corn, soybean, wheat, and oats. The period covered in this study is from January 24, 2020 to January 22, 2021. COVID-19 confirmed new cases and new deaths were retrieved from Our World in Data database (ourworldindata.org/coronavirus). Agricultural commodity prices, expressed in US Dollars per bushel, were obtained from Macrotrends database (macrotrends.net).

\section{Statistical Analysis}

Statistical analysis was performed by using GAUSS v.19.2 software. All variables are used in their natural logarithms. Figure 1 displays the natural log of our variables and their Fourier approximations. As it is shown in Figure 1, the Fourier approximation mimics the dynamics of the series very well.

\section{RESULTS}

Before applying the causality tests to investigate Granger causality linkage between agricultural commodity prices and COVID-19 caused new cases and new deaths, we employed the Augmented Dickey Fuller (ADF) unit root test proposed by Dickey and Fuller (51) and Fourier ADF unit root test suggested by Enders and Lee (52) to determine the maximum order of integration for TY approach. The unit root test results for the constant and trend model are reported in Table 1. According to the results, variables of COVID-19 new cases and new deaths reject the null of hypothesis of unit root at $1 \%$ significance level in their level, while all commodities do not reject the null hypothesis in their level. Since whole variables are stationary in their first difference, we determine the maximum order of integration as 1 .

After finding the maximum order of integration, next step for this study is to detect direction of causality among variables. The results from TY causality test are presented in Table 2. The results show that the null hypothesis of no-Granger causality from new cases to commodity prices is rejected for coffee, cotton, corn, and soybean. The results support information transmission from COVID-19 to commodity prices. The null hypothesis of no-Granger causality from new death to commodity prices is rejected for coffee, sugar, and cotton.

Table 3 shows the results from Fourier TY causality test. The findings from Fourier TY causality test are similar to that of TY test except causality from new cases to sugar price. This evidence implies that the causal relationship between COVID-19 and commodity prices are robust to structural changes in data. Besides, the Fourier TY causality test helped us confirm the robustness of the results with the TY causality test. Combining results from both tests, the findings provide evidence for COVID-19 information having predictive power for agricultural commodity prices except wheat and oats.

\section{DISCUSSION AND CONCLUSION}

COVID-19 pandemic have included negative consequences both in health management and economic life at the national and international level. The contamination of coronavirus and measures taken to relieve the adverse impacts of pandemic have transformed
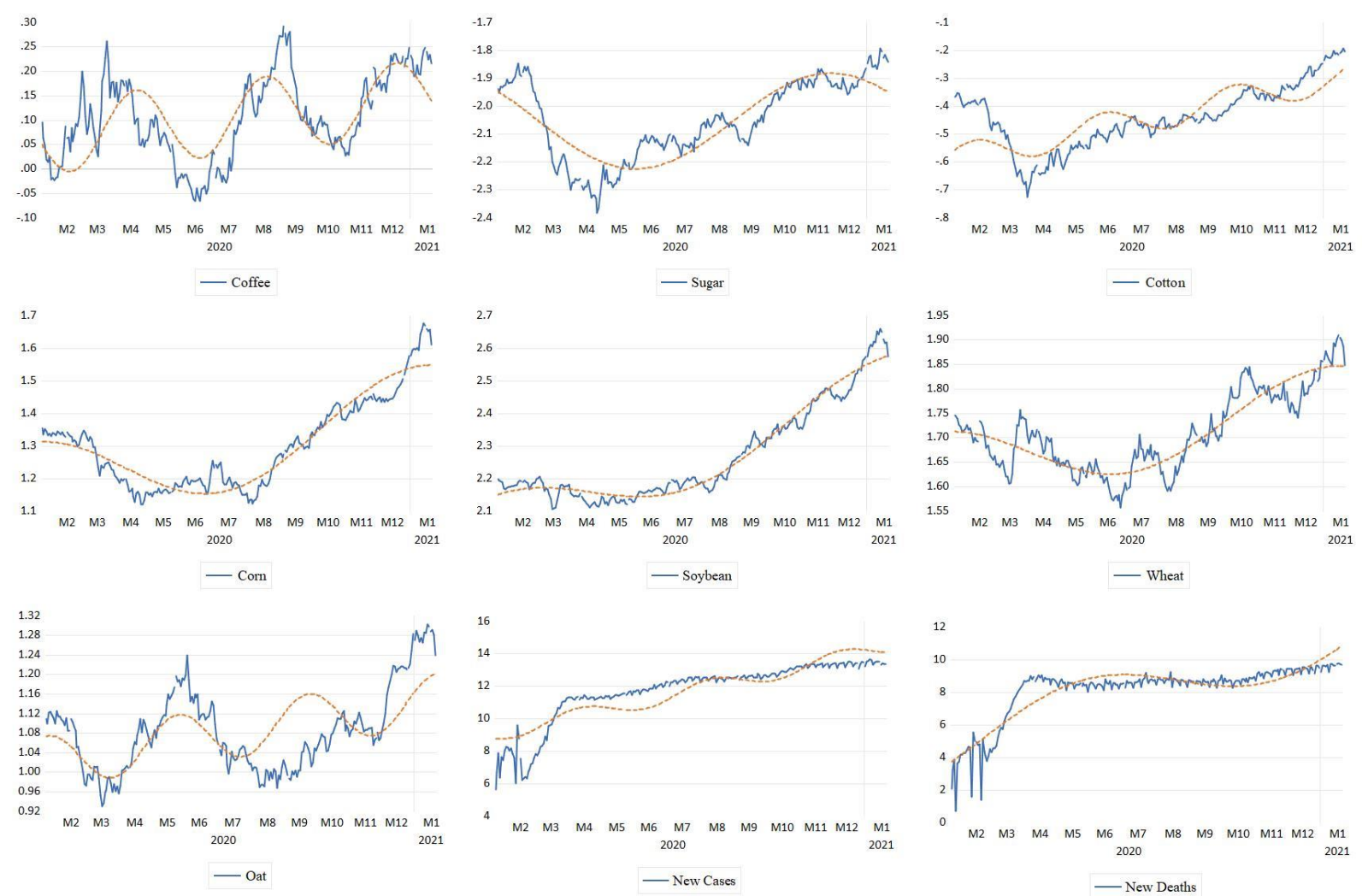

Figure 1. Dynamics of agricultural commodity prices and their Fourier approximations 
Table 1. Results from unit root tests

\begin{tabular}{|c|c|c|c|c|c|c|c|c|c|c|}
\hline \multirow[t]{2}{*}{ Variables } & \multicolumn{5}{|c|}{ Level } & \multicolumn{5}{|c|}{ First Difference } \\
\hline & $\mathrm{ADF}$ & & FADF & & $k$ & $\mathrm{ADF}$ & & FADF & & $k$ \\
\hline coffee & -2.377 & & -3.047 & & 3 & -14.712 & $* * *$ & -15.013 & $* * *$ & 3 \\
\hline sugar & -1.983 & & -2.344 & & 3 & -15.786 & $* * *$ & -16.132 & $* * *$ & 3 \\
\hline cotton & -2.399 & & -2.646 & & 3 & -15.069 & $* * *$ & -15.215 & $* * *$ & 3 \\
\hline corn & -1.343 & & -1.524 & & 3 & -13.602 & $* * *$ & -13.807 & $* * *$ & 3 \\
\hline soybean & -1.764 & & -3.655 & & 1 & -13.066 & $* * *$ & -13.068 & $* * *$ & 1 \\
\hline wheat & -2.502 & & -3.637 & & 1 & -16.393 & $* * *$ & -16.382 & $* * *$ & 2 \\
\hline oats & -1.691 & & -1.942 & & 3 & -14.763 & $* * *$ & -15.082 & $* * *$ & 3 \\
\hline new cases & -4.597 & $* * *$ & -5.681 & $* * *$ & 3 & -5.106 & $* * *$ & -5.679 & $* * *$ & 1 \\
\hline new deaths & -7.705 & $* * *$ & -7.153 & $* * *$ & 1 & -5.667 & $* * *$ & -6.633 & $* * *$ & 1 \\
\hline
\end{tabular}

represent significance level at 1,5, and 10 percent, respectively. $k$ denotes Fourier frequency. The maximum number of Fourier freque set to 3 and is selected by the minimization of sum of squared residuals as in Enders and Lee (51). The optimal lag(s) were determined by Schwarz information criterion. The critical values for ADF test are $-3.970(1 \%),-3.420(5 \%)$ and $-3.130(10 \%)$ and the critical values for FADF test are -4.870 (1\%), $-4.310(5 \%),-4.020(10 \%)$ for $\mathrm{k}=1 ;-4.620(1 \%),-4.010(5 \%),-3.690(10 \%)$ for $\mathrm{k}=2 ;-4.380(1 \%),-3.770(5 \%),-3.430(10 \%)$ for $\mathrm{k}=3(51, \mathrm{p} .197)$.

Table 2. Results from Toda-Yamamoto causality test

\begin{tabular}{|c|c|c|c|}
\hline Commodity & Wald & $\begin{array}{l}\text { Asymptotic } \\
\text { p-value }\end{array}$ & $\begin{array}{c}\text { Bootstrap } \\
\text { p-value }\end{array}$ \\
\hline \multicolumn{4}{|c|}{$H_{0}:$ New cases $\neq>$ commodity } \\
\hline coffee & $61.267 * * *$ & 0.000 & 0.000 \\
\hline sugar & 25.229 & 0.237 & 0.271 \\
\hline cotton & $30.671 *$ & 0.079 & 0.092 \\
\hline corn & $41.075 * *$ & 0.016 & 0.046 \\
\hline soybean & $39.107 *$ & 0.027 & 0.060 \\
\hline wheat & 21.886 & 0.586 & 0.601 \\
\hline oats & 27.165 & 0.297 & 0.298 \\
\hline \multicolumn{4}{|c|}{$H_{0}:$ New deaths $\neq>$ commodity } \\
\hline coffee & $54.870 * * *$ & 0.000 & 0.000 \\
\hline sugar & $29.693 *$ & 0.075 & 0.090 \\
\hline cotton & $32.409 *$ & 0.039 & 0.070 \\
\hline corn & 27.239 & 0.129 & 0.165 \\
\hline soybean & 15.387 & 0.754 & 0.723 \\
\hline wheat & 14.417 & 0.809 & 0.806 \\
\hline oats & 14.546 & 0.802 & 0.782 \\
\hline
\end{tabular}

***,**, and * show 1,5 , and 10 percent level of statistical significance, respectively. $\neq>$ denotes the null hypothesis of Granger non-causality. Bootstrap p-values are based on 1000 replications. The optimal $p$ are determined by Schwarz information criterion.

Table 3. Results from Fourier Toda-Yamamoto causality test

\begin{tabular}{|c|c|c|c|c|}
\hline Commodity & Wald & $\begin{array}{c}\text { Asymptotic } \\
\text { p-value }\end{array}$ & $\begin{array}{c}\text { Bootstrap } \\
\text { p-value }\end{array}$ & $k$ \\
\hline \multicolumn{5}{|c|}{$H_{0}:$ New cases $\neq>$ commodity } \\
\hline coffee & $61.184 * * *$ & 0.000 & 0.000 & 1 \\
\hline sugar & $35.135^{* *}$ & 0.027 & 0.048 & 3 \\
\hline cotton & $36.103 * *$ & 0.021 & 0.046 & 1 \\
\hline corn & $45.728 * *$ & 0.001 & 0.011 & 1 \\
\hline soybean & $42.548 * *$ & 0.004 & 0.018 & 1 \\
\hline wheat & 22.420 & 0.554 & 0.525 & 1 \\
\hline oats & 18.787 & 0.599 & 0.577 & 1 \\
\hline \multicolumn{5}{|c|}{$H_{0}:$ New deaths $\neq>$ commodity } \\
\hline coffee & $51.684 * * *$ & 0.000 & 0.000 & 3 \\
\hline sugar & $30.169 *$ & 0.050 & 0.090 & 3 \\
\hline cotton & $32.726^{* *}$ & 0.026 & 0.047 & 1 \\
\hline corn & 25.834 & 0.135 & 0.157 & 3 \\
\hline soybean & 16.403 & 0.630 & 0.612 & 1 \\
\hline wheat & 21.013 & 0.336 & 0.341 & 3 \\
\hline oats & 13.284 & 0.824 & 0.801 & 1 \\
\hline
\end{tabular}

***,**, and * show 1,5 , and 10 percent level of statistical significance, respectively. $\neq>$ denotes the null hypothesis of Granger non-causality. Bootstrap p-values are based on 1000 replications. The optimal $p$ and $k$ are determined by Schwarz information criterion. 
the socioeconomic life in the world. At the same time, COVID-19 cases and deaths have affected demand and supply in the agricultural sector and thereby agricultural commodity prices have demonstrated severe fluctuations throughout the year. This study was an attempt to examine the impact of COVID-19 spread on agricultural commodity prices. Particularly, we analyzed the causal relationship between COVID-19 pandemic and coffee, sugar, cotton, corn, soybean, wheat, and oats prices. We employed TY and Fourier TY Granger causality methods to test this relationship. The findings of our study demonstrated that there is a causal relationship leading from COVID-19 cases to coffee, sugar, cotton, corn, and soybean prices while there is no causality from COVID-19 new cases to wheat and oats prices. Moreover, we found that COVID-19 new deaths granger causes to coffee, sugar, and cotton whereas no causality is existing between COVID-19 deaths and corn, soybean, wheat, and oats prices. Our results are consistent with the previous study (43) covered in the literature part, which found that there is a causality running from COVID-19 deaths to corn prices. However, we reached the result of no causality from COVID-19 based new cases and deaths to oats and wheat prices. This result is different when compared to results of another research (45), which found that positive changes in oil prices during the COVID-19 period leads to positive response of wheat and corn prices. A potential explanation for these findings is that there is an evidence of causal relationship between COVID-19 and agricultural commodity prices beyond the nexus between stock markets, energy prices and COVID19 pandemic. Whereas estimating the impact of COVID-19 spread on stock markets, energy prices, and exchange rates has some merits, ignoring agricultural commodities such as coffee, sugar, and corn and their interaction with COVID-19 pandemic remains controversial. Overall, our findings can be interpreted to mean that COVID-19 cases and deaths are associated with agricultural commodity prices in the world and COVID-19 information is having predictive power for agricultural commodity prices except for wheat and oats. There are some probable threats for agricultural markets owing to the COVID-19 cases and deaths. First, changes in COVID-19 new cases and deaths in the world may have changes in coffee, sugar, cotton, corn, and soybean prices whereas no changes might be observed in wheat and oats prices. New cases and deaths due to the COVID-19 pandemic may affect labor supply in the agricultural markets and thereby supply chain in the agricultural products. Indeed, the spread of COVID-19 pandemic cause to shortages in coffee, sugar, cotton, corn, and soybean production and therefore the prices of these products might be influenced by these changes in the COVID-19 health management. Second, not only the supply side of agricultural market has been affected by the novel COVID-19 virus-based cases and deaths but also demand side of agricultural products are affected. COVID19 crisis might lead to disruption in countries' macroeconomic conditions. Slow-down in economic activities might cause to drop in income and thereby affecting the demand of coffee, sugar, cotton, corn, and soybean. Because of changes in demand, the prices of coffee, sugar, cotton, corn, and soybean might be affected. The COVID-19 process caused profound changes in health systems management. As COVID-19 related cases and deaths increased, health management began to have more difficulties. However, this process also led to significant changes in economic and social life, especially in the agricultural sector. In addition to the curfews in countries and the decrease in total demand, the supply chain management was adversely affected by the pandemic and the virus spread rapidly among economic actors in the agricultural market. Because of the fact that there is a causal relationship between COVID-19 caused new cases and new deaths and agricultural commodity prices, policymakers should design the COVID-19 related health and agricultural commodity policies together. Regarding the deficiencies in health management systems, the spread of COVID-19 diseases among employees should be reduced and vaccination priority should be given to economic actors in the agricultural sector. Moreover, supply chain management in the agricultural sector should be strengthened by providing economic and health support to producers. Hence, this topic should deserve further research.

Ethics Committee Approval: Since our study was not an experimental study including human or animal subject, ethics committee approval was not required.

Conflict of Interest: None declared by the authors.

Financial Disclosure: None declared by the authors.

Acknowledgements: None declared by the authors.

Author Contributions: Idea/Concept: ETK, MA; Design: ETK, MA; Data Collection/Processing: MA, ÇK; Analysis/Interpretation: ETK, MA, ÇK; Literature Review: ETK, MA; Drafting/Writing: ETK, MA, ÇK; Critical Review: ETK.

\section{REFERENCES}

1. who.int [Internet]. World Health Organization. Listings of WHO's response to COVID-19. [Cited: 2020 Dec 31]. Available from: https://www. who.int/news/item/29-06-2020-covidtimeline

2. Ji Y, Ma Z, Peppelenbosch MP, Pan Q. Potential association between COVID-19 mortality and healthcare resource availability. Lancet Glob Health. 2020;8(4):e480.

3. Mas-Coma S, Jones MK, Marty AM. COVID-19 and globalization. One Health. 2020;9:100132.

4. Qian M, Jiang J. COVID-19 and social distancing. J Public Health (Berl). 2020. doi: 10.1007/s10389-02001321-z 1-3.

5. oecd.org [Internet]. Organization for Economic Cooperation and Development. The territorial impact of COVID-19: Managing the crisis across levels of government. [Cited: 2020 Dec 30]. Available from: https://read.oecd-ilibrary.org/view/?ref=128_1282875agkkojaaa\&title=The-territorial-impact-of-covid-19managing-the-crisis-across-levels-of-government

6. oecd.org [Internet]. Organization for Economic Cooperation and Development. Coronavirus (COVID19): SME policy responses. [Cited: 2021 Jan 01]. Available from: https://read.oecd-ilibrary.org/view/ 
?ref=119_119680-di6h3qgi4x\&title=Covid-

19_SME_Policy_Responses

7. oecd.org [Internet]. Organization for Economic Cooperation and Development. Tax and fiscal policy in response to the coronavirus crisis: Strengthening confidence and resilience. [Cited: 2020 Dec 31]. Available from: https://read.oecd-ilibrary.org/view/ ?ref=128_128575-o6raktc0aa\&title=Tax-and-FiscalPolicy-in-Response-to-the-Coronavirus-Crisis

8. Legido-Quigley $\mathrm{H}$, Mateos-García JT, Campos VR, Gea-Sánchez M, Muntaner C, McKee M. The resilience of the Spanish health system against the COVID-19 pandemic. Lancet Public Health. 2020;5(5):e251-2.

9. Armocida B, Formenti B, Ussai S, Palestra F, Missoni E. The Italian health system and the COVID-19 challenge. Lancet Public Health. 2020;5(5):e253.

10. Blumenthal D, Fowler EJ, Abrams M, Collins SR. COVID-19 implications for the health care system. N Engl J Med. 2020;383(15):1483-8.

11. National Academy of Engineering and Institute of Medicine. Building a better delivery system: a new engineering/health care partnership. Washington, DC: The National Academies Press; 2005.

12. Gao X, Yu J. Public governance mechanism in the prevention and control of the COVID-19: information, decision-making and execution. $J$ Chin Gov. 2020;5(2):178-97.

13. oecd.org [Internet]. Organization for Economic Cooperation and Development. COVID-19 and the food and agriculture sector: issues and policy responses. [Cited: 2020 Dec 31]. Available from: https://read.oecd-ilibrary.org/view/?ref=130_1308169uut45lj4q\&title=Covid-19-and-the-food-andagriculture-sector-Issues-and-policy-responses

14. Jámbor A, Czine P, Balogh P. The impact of the coronavirus on agriculture: first evidence based on global newspapers. Sustainability. 2020;12(11):4535.

15. worldbank.org [Internet]. The World Bank. Most commodity prices to drop in 2020 as coronavirus depresses demand and disrupts supply. [Cited: 2021 Jan 03]. Available from: https://www.worldbank.org/ en/news/press-release/2020/04/23/most-commodityprices-to-drop-in-2020-as-coronavirus-depressesdemand-and-disrupts-supply

16. Bakas D, Triantafyllou A. Commodity price volatility and the economic uncertainty of pandemics. Econ Lett. 2020;193:109283.

17. Andersen TM, Hansen NL. Price adjustment in open economies. Open Econ Rev. 1995;6(4):303-21.

18. fao.org [Internet]. Food and Agriculture Organization of the United Nations. Migrant workers and the COVID-19 pandemic. [Cited: 2021 Jan 04]. Available from: http://www.fao.org/policy-support/tools-andpublications/resources-details/en/c/1270461/

19. worldbank.org [Internet]. The World Bank. Food Security and COVID-19. [Cited: 2021 Jan 02]. Available from: https://www.worldbank.org/ en/topic/agriculture/brief/food-security-and-covid-19

20. Rawal V, Verma A. Agricultural supply chains during the COVID-19 lockdown: A study of market arrivals of seven key food commodities in India. SSER Monograph 20/1. New Delhi, India: Society for Social and Economic Research; 2020.
21. Kerr WA. The COVID-19 pandemic and agriculture: Short-and long-run implications for international trade relations. Can J Agric Econ. 2020;68(2):225-9.

22. Albulescu CT. COVID-19 and the United States financial markets' volatility. Financ Res Lett. 2021;38:101699.

23. Ashraf BN. Stock markets' reaction to COVID-19: Cases or fatalities? Res Int Bus Finance. 2020;54:101249.

24. Hassan S. Riveros-Gavilanes JM. First to react is the last to forgive: Evidence from the stock market impact of COVID-19. J Risk Financial Manag. 2021;14(1):26.

25. Onali E. COVID-19 and stock market volatility. SSRN. 2020. doi: 10.2139/ssrn.3571453.

26. Topcu M, Gulal OS. The impact of COVID-19 on emerging stock markets. Financ Res Lett. 2020;36:101691.

27. Xu L. Stock return and the COVID-19 pandemic: evidence from Canada and the US. Financ Res Lett. 2021;38:101872.

28. Ozili PK, Arun T. Spillover of COVID-19: impact on the global economy. SSRN. 2020. doi: 10.2139/ssrn.3562570.

29. Anh DLT, Gan C. The impact of the COVID-19 lockdown on stock market performance: evidence from Vietnam. J Econ Stud. 2020;[Epub ahead of print]. doi: 10.1108/JES-06-2020-0312.

30. Apergis N, Apergis E. The role of COVID-19 for Chinese stock returns: evidence from a GARCHX model. Asia-Pac J Account Econ. 2020; [Epub ahead of print]. doi: 10.1080/16081625.2020.1816185

31. Umar M, Rubbaniy G, Rizvi SKA. COVID-19 and stock market liquidity: An international evidence. SSRN. 2020. doi: 10.2139/ssrn.3758201.

32. Celik I, Yilmaz T, Emir S, Sak AF. The effects of COVID-19 outbreak on financial markets. Financial Studies. 2020;24(4):6-28.

33. Şit A, Telek C. Effects of COVID-19 pandemic on gold ounce price and dollar index. Gaziantep University Journal of Social Sciences. 2020;19(Special Issue):113.

34. Unvan YA. Investigation of causality relationships among COVID-19 cases, ISE100 index, dollar, euro, gram gold prices and 2 years bond rates: The case of Turkey. Alphanumeric Journal. 2020;8(1):29-42.

35. Yousef I, Shehadeh E. The impact of the COVID-19 on gold price volatility. Int $\mathbf{J}$ Econ Bus Adm. 2020;8(4):353-64.

36. Sar1 SS, Kartal T. The relationship of COVID-19 pandemic with Gold Prices, Oil Prices and VIX Index. Erzincan University Journal of Social Sciences Institute. 2020;13(1):93-109.

37. Chowdhury EK, Abedin MZ. COVID-19 Effects on the US stock index returns: An event study approach. SSRN. 2020. doi: 10.2139/ssrn.3611683.

38. Chen C, Liu L, Zhao N. Fear sentiment, uncertainty, and bitcoin price dynamics: The case of COVID-19. Emerg Mark Finance Trade. 2020;56(10):2298-309.

39. Fasanya IO, Oyewole O, Adekoya OB, Odei-Mensah J. Dynamic spillovers and connectedness between COVID-19 pandemic and global foreign exchange markets. Econ Res-Ekon Istraž. 2020; [Epub ahead of print]. doi: 10.1080/1331677X.2020.1860796. 
40. Yousef I. Spillover of COVID-19: Impact on stock market volatility. Int $\mathrm{J}$ Psychosoc Rehabilitation. 2020;24(6):18069-81.

41. Ibrahim I, Kamaludin K, Sundarasen S. COVID-19, government response, and market volatility: Evidence from the Asia-Pacific developed and developing markets. Economies. 2020;8(4):105.

42. Erdoğan S, Yıldırım DÇ, Gedikli A. Dynamics and determinants of inflation during the COVID-19 pandemic period in European countries: A spatial panel data analysis. Duzce Med J. 2020;22(S1):61-7.

43. Gok R, Kara E. Impacts of the COVID-19 pandemic on the agricultural prices: New insights from CWT Granger causality test. Journal of Research in Economics Politics and Finance. 2020;5(Special Issue):76-96.

44. Elleby C, Domínguez IP, Adenauer M, Genovese G. Impacts of the COVID-19 pandemic on the global agricultural markets. Environ Resource Econ. 2020;76(4):1067-79.

45. Ezeaku HC, Asongu SA, Nnanna, J. Volatility of international commodity prices in times of COVID-19: Effects of oil supply and global demand shocks. Extr Ind Soc. 2021;8(1):257-70.
46. Kotyza P, Czech K, Wielechowski M, Smutka L, Procházka $\mathrm{P}$. Sugar prices vs. financial market uncertainty in the time of crisis: Does COVID-19 induce structural changes in the relationship? Agriculture. 2021;11(2):93.

47. Nazlioglu S, Gormus NA, Soytas U. Oil prices and real estate investment trusts (REITs): Gradual-shift causality and volatility transmission analysis. Energy Econ. 2016;60:168-75.

48. Toda HY, Yamamoto T. Statistical inference in vector autoregressions with possibly integrated processes. J Econom. 1995;66(1-2):225-50.

49. Granger CW. Investigating causal relations by econometric models and cross-spectral methods. Econometrica. 1969;37(3):424-38.

50. Enders W, Jones P. Grain prices, oil prices, and multiple smooth breaks in a VAR. Stud Nonlinear Dyn E. 2016;20(4):399-419.

51. Dickey DA, Fuller WA. Distribution of the estimators for autoregressive time series with a unit root. J Am Stat Assoc. 1979;74(366):427-31.

52. Enders W, Lee J. The flexible Fourier form and Dickey-Fuller type unit root tests. Econ Lett. 2012;117(1):196-9. 